\title{
Efficiency of Microfinance Institutions in India: Evidence from Malmquist Indices
}

\author{
Duong Hoai $\mathrm{An}^{1}$ \\ ${ }^{1}$ Faculty of Economics and Rural Development, Thai Nguyen University of Agriculture and Forestry, Quyet \\ Thang Commune, Thai Nguyen City, Vietnam \\ Correspondence: Duong Hoai An, Faculty of Economics and Rural Development, Thai Nguyen University of \\ Agriculture and Forestry, Quyet Thang Commune, Thai Nguyen City, Vietnam. Tel: 84-2082-759-761.
}

Received: December 7, 2017

Accepted: December 20, 2017

Online Published: December 28, 2017

doi:10.20849/iref.v1i1.269

URL: https://doi.org/10.20849/iref.v1i1.269

\begin{abstract}
The current study constructs a balanced panel data set on microfinance institutions in India during 2008-2012 and employs a data envelopment analysis to examine the efficiency of the institutions. The results show a decrease of 0.3 per cent in productivity during the study period. In addition, the technical efficiency change, pure efficiency change and scale efficiency attributes to the overall inefficiency of the institutions. Also, profit institutions are more efficient than non-profit institutions. Results from Tobit regressions indicate that the impact of population and GDP on the efficiency of the institutions is significant, but that of the number of microfinance institutions is not.
\end{abstract}

Keywords: efficiency, productivity, Malmquist indices, DEA, microfinance, India

\section{Introduction}

Microfinance is considered as one of the effective tools to fight against poverty. The efficiency of microfinance institutions (MFIs) has long been of interest to managers, policy makers and stakeholders. Performance indicators of MFIs can be used as inputs and outputs to examine the efficiency of the institutions.

The current study contributes to the literature in a number of ways. Firstly, it constructs a strongly balanced panel data set from 2008 to 2012 for analyses. Secondly, it applies the DEA techniques to produce the Malmquist indices, which are used to examine the efficiency of the institutions. Thirdly, it splits the sample into sub-samples for further analyses and comparisons. Finally, it examines the impact of external factors on the efficiency of the MFIs.

Results from the non-parametric analysis show that productivity of the institution during the study period decreases by 0.3 per cent. The productivity growth is negative in 2009 , but positive in other years. The decomposition of the total factor productivity change shows that the technical efficiency change, pure efficiency change and scale efficiency attributes to the overall inefficiency of the institutions. The results also show that profit and regulated institutions are more efficient than non-profit and non-regulated institutions, respectively. The parametric analysis using a Tobit regression shows that the impact of population and GDP on the efficiency of the institutions is significant at 10 per cent level, but that of the number of MFIs is not significant.

The structure of this paper is organised as follows: Section 2 reviews the literature on microfinance efficiency studies. Methodology, data, and variable description are discussed in Section 3 whilst results and discussions are presented in Section 4 and Section 5 concludes.

\section{Literature Review}

There have been a number of studies examined the efficiency of MFIs. However, very few studies on the impact of external factors on the efficiency of MFIs are available. Therefore, studies on the impact of external factors on the efficiency of institutions are reviewed in the current study. The relevant studies in India and international contexts are briefly reviewed as follows.

\subsection{International Studies}

Bassem (2008) used data from MIX Market and applied DEA to examine the efficiency of 35 MFIs in the Mediterranean region. Two inputs (number of employees, including staff and total assets) and two outputs (the 
number of female borrowers and return on assets-ROA) were used with the production approach. Both the constant returns on scale (CRS) and variable returns on scale (VRS) are analysed. Results from the CRS model showed that only 5 out of 35 MFIs were efficient in both years. The number of MFIs found to be efficient by the VRS model was higher ( 9 out of 35 in 2004 and 8 out of 35 in 2005). Based on the average inefficiency generated by the CRS model, the institutions could have been able to produce the same amount of outputs with only 55.18 and 56.75 per cent of their inputs in 2004 and 2005, respectively. According to the average inefficiency produced by the VRS model, the institutions could have been able to produce the same amount of outputs with only 39.38 and 42.82 per cent of their inputs used in 2004 and 2005, respectively. The study concluded that the MFI size had a negative impact on the efficiency of the institution. However, the impact of external factors on the efficiency scores of the institutions was not analysed in this study.

Ahmad (2011) used 2003 and 2007 cross-sectional data obtained from the Pakistan Microfinance Network to examine the efficiency of MFIs in Pakistan (Although the author stated clearly that the second data set was for 2007 (on page 12), the results presented as the year of 2009. It is therefore, assumed the second data set was for 2009). Both input and output-oriented approaches were applied and both CRS and VRS models were used. Gross loan portfolio and number of active borrowers were used as outputs while total assets and number of personnel were employed as inputs. The results showed that in 2003, only 3 out of 12 MFIs were efficient and in 2009, 4 out of 19 MFIs were efficient. The study also showed that the efficiency of the MFIs in 2003 and 2009 could have been improved by 45.2 and 42.9 per cent, respectively. The impact of external factors on the efficiency scores of the institutions was not examined in this study.

Annim (2012) sourced data from MIX Market and the World Bank to construct a balanced panel data set of 164 MFIs from five regions across the world during 2004-2008. Both parametric (Stochastic Frontier Analysis-SFA) and non-parametric (DEA) techniques were used in this study. The study followed a three-stage analysis to estimate the efficiency: First, it used DEA (both CRS and VRS) techniques to calculate the efficiency scores for the MFIs. Next, it estimated the Simar and Wilson's bias-corrected scores and run a regression on the explanatory variables. Finally, it benchmarked results obtained from the second estimation with a Translog cost frontier parametric analysis. Input variables used in this study include operating expense, personnel, cost per staff and cost per loan. Output variables comprise gross portfolio, financial revenue and the number of female borrowers. The efficiencies were decomposed into pure efficiency and scale efficiency for sub-samples (by region and by type of MFIs). The results showed that managerial performance improved, but the scale size of the institutions was less and less optimum during the study period. For example, the average pure technical efficiency for narrow sustainability increased from 42.7 per cent in 2004 to 54.3 per cent in 2008 . The average scale efficiency for the same study period for the same sub-sample decreased from 85.6 to 85 per cent. This study also investigated the impact of characteristics of MFIs (internal factors) on the efficiency of the institution. Results from the bias-corrected pure technical regression showed that the operational self-sufficiency (OSS) had a positive impact while the grants as a source of funds had a negative impact on the narrow financial efficiency; both were significant at one per cent. The credit information index and the OSS had a positive impact while the ratio of domestic credit to GDP had a negative impact on the broad financial efficiency; the impact of these variables was significant at one per cent. Results from the stochastic frontier regression showed that cost per borrower and gross loan portfolio were positively associated with inefficiency, both were significant at one per cent level.

Kipesha (2012) obtained data of 35 MFIs in 2009, 2010 and 2011 from MIX Market and used both CRS and VRS models to examine the efficiency of the MFIs in five countries in the East of Africa. Input variables consist of total assets, personnel and operating revenues while output variables comprise gross loan portfolio and financial revenue. The results showed that, under the CRS assumption, 5, 8 and 11 MFIs were efficient in 2009, 2010 and 2011, respectively. Under the VRS assumption, 12, 16 and 17 MFIs were efficient in 2009, 2010 and 2011, respectively. The results also show that the efficiency of the institution improved during the study period. The technical efficiencies generated under the CRS assumption show that the institutions could reduce the use of their inputs by 29.4, 20,2 and 14.8 per cent in 2009, 2010 and 2011, respectively, without changing their outputs. Under the VRS assumption, the results indicate that these institutions could reduce their inputs by $17.7,10.8$ and 10.9 per cent in 2009, 2010 and 2011, respectively, keeping the outputs unchanged. The pure technical efficiencies show that managerial performance could be improved. For example, in 2009, approximately 17.7 per cent of 29.4 of the overall technical inefficiency were caused by managerial underperformance. Similarly, the scale size of the institutions could have been optimized to be efficient. For example, inappropriate size of the institutions in 2011 attributed 4.4 per cent out of 10.9 of the overall technical inefficiency. The impact of external factors on the efficiency scores of the institutions was not explored in this study. 
Tahir and Tahrim (2015) collected data on 13 MFIs operating in Cambodia during 2008-2011 from MIX Market and used DEA to calculate efficiency scores and Malmquist indices to analyse the efficiency of the institutions. The study followed the production approach with two inputs (total assets and operating expenses) and two outputs (gross loan portfolio and number of active borrowers). The efficiency scores show that although the efficiency of the institutions improved during the study period (the efficiency means were 91.1, 92.1, 92 and 92.7 per cent in 2008, 2009, 2010 and 2011, respectively), the overall efficiency of the institutions during the study period was 92 per cent, suggesting eight per cent to be improved by correctly combining inputs and outputs. Results from the Malmquist productivity indices show an increase of 1.7 per cent in productivity during 2008-2009, a decrease of 0.6 per cent during 2009-2010 and an increase of 0.9 per cent in the period of 2010-2011. While technology, technical efficiency and scale size of the institutions promoted the productivity growth in the period of 2008-2009, managerial underperformance undermined productivity growth in this period. The period of 2009-2010 observed improvements in technical efficiency and scale size of the institutions, but the inefficiencies in technology and management attributed to the decrease in productivity growth. Improvements in technology and management during 2010-2011 contributed to the improvement in productivity growth.

Gebremichael et al. (2016) used the stochastic frontier analysis approach to examine the technical efficiency of 134 MFIs in 36 countries in Africa. Their results showed that the average technical efficiency score was almost 0.49 , indicating that their outputs could have doubled with the inputs unchanged. They also found that the efficiency of the MFIs was significantly different among different ownership types.

Takundwa et al. (2017) used Tobit regressions to examine the impact of three external factors such as population size, prevalence of disease, and unemployment rates on the efficiency of clinical commissioning groups in England. The results show that population, prevalence of disease and unemployment rates had a significant impact on the efficiency of the groups. Particularly, clinical commissioning groups with larger population sizes were not as efficient as those with smaller population sizes. In addition, high unemployment rates and a high prevalence of chronic obstructive pulmonary disease reduced efficiency scores of the groups.

\subsection{Studies on the Efficiency of Microfinance Institutions in India}

Despite considerable efforts of the author, very limited papers on the efficiency of MFIs in India are found. Therefore, working papers are included in this section to review.

Masood and Ahmad (2010) constructed an unbalanced panel data set (obtained from MIX Market) of 40 MFIs operating during 2005-2008 to examine the efficiency of the institutions and the determinants of the efficiency. A stochastic frontier analysis approach with two models was used in this study. The first model (stochastic frontier analysis) was used to inspect the impact of personnel and cost per borrower on gross loan portfolio. The second model (technical inefficiency) was employed to examine the impact of assets, age of the institution, ratio of debt to equity and number of active borrowers on the technical inefficiency. Results showed that both personnel and cost per borrower had a positive impact on gross loan portfolio and the impact of both variables was significant at five per cent level. Also, both age of MFIs and number of active borrowers improved efficiency of the institutions, and the impact of both variables was significant at five per cent level. The study also conducted a brief non-parametric analysis. The efficiency mean showed that the institutions could have increased outputs by 66 per cent using the same amount of inputs.

Agarwal and Sinha (2010) collected data on 22 five-start MFIs operating in India in 2008 to conduct a statistical analysis on the financial performance of the institutions. Instead of using inputs and outputs, the study used financial performance, which is represented by financial structure, revenue, expenses, efficiency, productivity and risk, available from the data source. The study conducted a number of descriptive statistics to examine the financial efficiency of the institutions. The results varied among the selected indicators. For example, the ratio of capital to asset, deposits to loans, deposits to assets, gross loan portfolio to total assets was significant, mostly at 10 per cent. However, the ratio of debt to equity, borrowers per staff member was not significant.

It can be seen that the most popular data source in the previous studies was from MIX Market. Common inputs were total assets and operating expenses while outputs were gross loan portfolio, number of active borrowers and number of female borrowers. A number of the studies focused on calculating efficiency scores while a few attempted to decompose the technical efficiency or the total factor productivity for a further analysis. The most common method used in the previous studies to examine the efficiency of MFIs was non-parametric, a few included parametric (mainly SFA) to investigate the impact of external factors on the efficiency of the institutions. Findings from the previous studies showed that there is room for improvement in efficiency of the institutions. Level of efficiency depends on the selection of inputs and outputs. The most common external factors that significantly influenced efficiency of the institutions (examined by SFA methods) were number of 
active borrowers, personnel and operational self-sufficiency. A study applied Tobit regressions and found that the impact of population size, prevalence of disease, and unemployment rates on the efficiency of clinical commissioning groups in England was statistically significant.

To the best of the author's knowledge, none of the previous studies used panel data during 2008-2012 to calculate the Malmquist index and its components in order to examine the efficiency of MFIs in India. Also, none of those studies attempted to compare the efficiency of profit and regulated MFIs with that of non-profit and non-regulated MFIs, respectively.

\section{Methodology, Data and Variable Selection}

\subsection{Conceptual Framework and Methodology}

An institution can use $\mathrm{n}$ inputs to produce $\mathrm{m}$ outputs. External factors such as social, economic and political situations can influence the institution while it is making decision. This process is described in Figure 1 bellow.

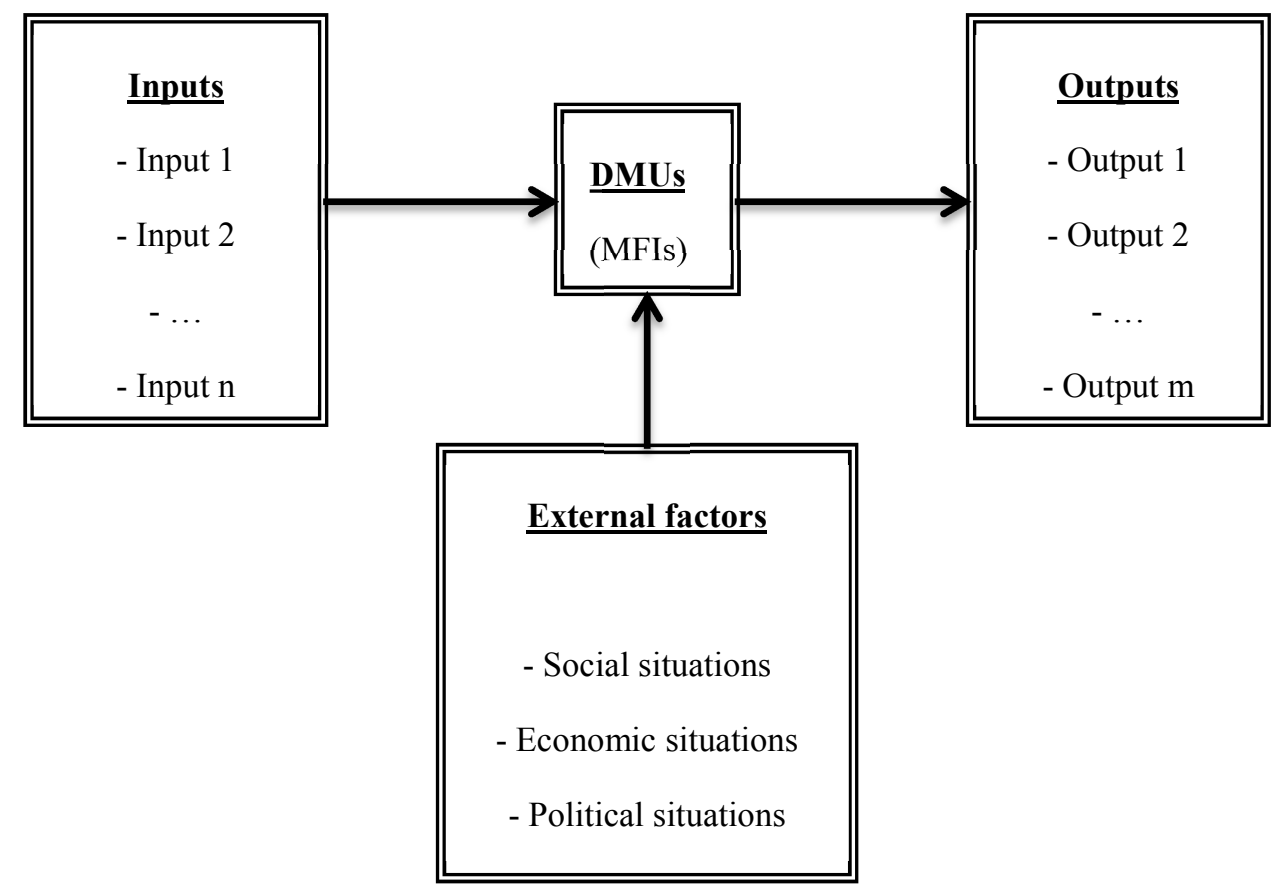

Figure 1. Conceptual framework of decision-making process of institution

Source: Designed by the author, ideas adopted from the literature.

Basically, data envelopment analysis (DEA) approach examines whether or not the combination of inputs and outputs of a firm is efficient. This combination can be viewed from two perspectives: one is known as input-oriented approach where the firm has control over its inputs, hence can minimise the use of its inputs to produce given outputs. The other approach is seen as output-oriented approach where the organisation can maximise its outputs using given inputs (Coelli, Rao, O’Donnell, \& Battese, 2005). The current study follows the output-oriented approach with an assumption that the managers of the institution tend to maximise outputs, such as by providing more loans to more clients, using limited of given inputs.

The technical efficiency with output-oriented approach can be obtained by solving the following problem:

$$
\begin{aligned}
& \max _{\theta, \lambda} \theta \\
& \text { Subject to }\left\{\begin{array}{l}
-\theta \mathrm{y}_{\mathrm{i}}+\mathrm{Y} \lambda \geq 0 \\
\mathrm{x}_{\mathrm{i}}-\mathrm{X} \lambda \geq 0 \\
\mathrm{I} 1^{\prime} \lambda=1 \\
\lambda \geq 0
\end{array}\right.
\end{aligned}
$$

where $1 \leq \theta \leq \infty, \theta$ is a scalar representing technical efficiency, and $\theta-1$ is the proportional increase in outputs $\left(\mathrm{y}_{\mathrm{i}}\right)$, which could be obtained by the $\mathrm{i}^{\text {th }}$ firm with fixed inputs $\left(\mathrm{x}_{\mathrm{i}}\right) . \lambda$ is a vector of weights, representing the 
distance between an efficient MFI and its peers. Y and X represent the matrices of outputs and inputs, respectively, of all MFIs in the data.

The present study takes advantage of the availability of panel data from 2008 to 2012 to generate the total factor productivity change and its components. These are believed to give more insights into the efficiency of the institutions. The Malmquist Total Factor Productivity (TFP) Index was first introduced by (Caves, Christensen, \& Diewert, 1982a, 1982b) (The Total factor productivity change and the Malmquist total productivity index are used interchangeably in this study). The index is calculated by measuring the radial distance of the output (y) and input $(\mathrm{x})$ vectors in $\mathrm{t}$ and $\mathrm{t}+1$ periods. The Malmquist index for period $\mathrm{t}$ is defined as follows:

$$
\mathrm{m}_{\mathrm{o}}^{\mathrm{t}}\left(\mathrm{y}_{\mathrm{i}}^{\mathrm{t}}, \mathrm{y}_{\mathrm{i}}^{\mathrm{t}+1}, \mathrm{x}_{\mathrm{i}}^{\mathrm{t}}, \mathrm{x}_{\mathrm{i}}^{\mathrm{t}+1}\right)=\frac{\mathrm{d}_{\mathrm{o}}^{\mathrm{t}}\left(\mathrm{y}_{\mathrm{i}}^{\mathrm{t}+1}, \mathrm{x}_{\mathrm{i}}^{\mathrm{t}+1}\right)}{\mathrm{d}_{\mathrm{o}}^{\mathrm{t}}\left(\mathrm{y}_{\mathrm{i}}^{\mathrm{t}}, \mathrm{x}_{\mathrm{i}}^{\mathrm{t}}\right)}
$$

where $\mathrm{m}_{\mathrm{o}}$ denotes the Malmquist index and $\mathrm{d}_{\mathrm{o}}$ refers to the output distance function.

If the firm is technically efficient in both periods, then the denominator in equation 2 equals one and therefore:

$$
\mathrm{m}_{\mathrm{o}}^{\mathrm{t}}\left(\mathrm{y}_{\mathrm{i}}^{\mathrm{t}}, \mathrm{y}_{\mathrm{i}}^{\mathrm{t}+1}, \mathrm{x}_{\mathrm{i}}^{\mathrm{t}}, \mathrm{x}_{\mathrm{i}}^{\mathrm{t}+1}\right)=\mathrm{d}_{\mathrm{o}}^{\mathrm{t}}\left(\mathrm{y}_{\mathrm{i}}^{\mathrm{t}+1}, \mathrm{x}_{\mathrm{i}}^{\mathrm{t}+1}\right)
$$

Similarly, the Malmquist index for period $\mathrm{t}+1$ is defined as:

$$
\mathrm{m}_{\mathrm{o}}^{\mathrm{t}+1}\left(\mathrm{y}_{\mathrm{i}}^{\mathrm{t}}, \mathrm{y}_{\mathrm{i}}^{\mathrm{t}+1}, \mathrm{x}_{\mathrm{i}}^{\mathrm{t}}, \mathrm{y}_{\mathrm{i}}^{\mathrm{t}+1}\right)=\frac{\mathrm{d}_{\mathrm{o}}^{\mathrm{t}+1}\left(\mathrm{y}_{\mathrm{i}}^{\mathrm{t}+1}, \mathrm{x}_{\mathrm{i}}^{\mathrm{t}+1}\right)}{\mathrm{d}_{\mathrm{o}}^{\mathrm{t}+1}\left(\mathrm{y}_{\mathrm{i}}^{\mathrm{t}}, \mathrm{x}_{\mathrm{i}}^{\mathrm{t}}\right)}
$$

If the firm is technically efficient in period $t+1$, then the numerator in equation 4 equals one.

The total factor productivity change (TFPCH) between period $t$ and period $t+1$ is:

$$
\text { TFPCH }=\left[\mathrm{m}_{\mathrm{o}}^{\mathrm{t}}\left(\mathrm{y}_{\mathrm{i}}^{\mathrm{t}}, \mathrm{y}_{\mathrm{i}}^{\mathrm{t}+1}, \mathrm{x}_{\mathrm{i}}^{\mathrm{t}}, \mathrm{x}_{\mathrm{i}}^{\mathrm{t}+1}\right) * \mathrm{~m}_{\mathrm{i}}^{\mathrm{t}+1}\left(\mathrm{y}_{\mathrm{i}}^{\mathrm{t}}, \mathrm{y}_{\mathrm{i}}^{\mathrm{t}+1}, \mathrm{x}_{\mathrm{i}}^{\mathrm{t}}, \mathrm{x}_{\mathrm{i}}^{\mathrm{t}+1}\right)\right]^{\frac{1}{2}}=\left[\frac{\mathrm{d}_{\mathrm{o}}^{\mathrm{t}}\left(\mathrm{y}_{\mathrm{i}}^{\mathrm{t}+1}, \mathrm{x}_{\mathrm{i}}^{\mathrm{t}+1}\right)}{\mathrm{d}_{\mathrm{o}}^{\mathrm{t}}\left(\mathrm{y}_{\mathrm{i}}^{\mathrm{t}}, \mathrm{x}_{\mathrm{i}}^{\mathrm{t}}\right)} * \frac{\mathrm{d}_{\mathrm{o}}^{\mathrm{t}+1}\left(\mathrm{y}_{\mathrm{i}}^{\mathrm{t}+1}, \mathrm{x}_{\mathrm{i}}^{\mathrm{t}+1}\right)}{\mathrm{d}_{\mathrm{o}}^{\mathrm{t}+1}\left(\mathrm{y}_{\mathrm{i}}^{\mathrm{t}}, \mathrm{x}_{\mathrm{i}}^{\mathrm{t}}\right)}\right]
$$

Equation 5 above can be re-written as:

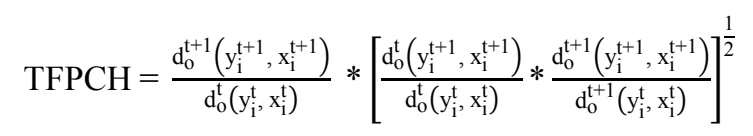

In equation 6 , the ratio outside the square bracket measures technical efficiency change (EFFCH) while those inside the square bracket measure technological change (TECHCH). Or:

$$
\mathrm{TFPCH}=\mathrm{EFFCH} * \mathrm{TECHCH}
$$

EFFCH shows how well the firm is in managing its inputs and outputs. If a firm could have used fewer inputs than its current inputs to keep its outputs unchanged, it is considered inefficient. Similarly, if a firm could have produced more outputs than its current outputs using the same amount of inputs, it is not efficient.

Technology is assumed to change or develop overtime. A firm that is able to apply or update to new technology likely to be efficient (by either minimising the use of inputs or maximising outputs) and the availability of panel data allows to observe this change over time. TECHCH shows the ability of the firm to catch up with modern technology (Coelli et al., 2005).

Färe, Grosskopf, Norris, and Zhang (1994) decomposed EFFCH to be pure technical efficiency change (PECH) and scale efficiency change $(\mathrm{SECH})$ for further analyses as follows:

$$
\mathrm{EFFCH}=\mathrm{PECH} * \mathrm{SECH}
$$

where:

$$
\begin{aligned}
& \text { PECH }=\frac{d_{v}^{t+1}\left(y_{i}^{t+1}, x_{i}^{t+1}\right)}{d_{v}^{t}\left(y_{i}^{t}, x_{i}^{t}\right)} \\
& \mathrm{SECH}=\frac{\frac{\mathrm{d}_{\mathrm{c}}^{\mathrm{t}+1}\left(\mathrm{y}_{\mathrm{i}}^{\mathrm{t}+1}, \mathrm{x}_{\mathrm{i}}^{\mathrm{t}+1}\right)}{\mathrm{d}_{\mathrm{v}}^{\mathrm{t}+1}\left(\mathrm{y}_{\mathrm{i}}^{\mathrm{t}+1}, \mathrm{x}_{\mathrm{i}}^{\mathrm{t}+1}\right)}}{\frac{\mathrm{d}_{\mathrm{c}}^{\mathrm{t}}\left(\mathrm{y}_{\mathrm{i}}^{\mathrm{t}}, \mathrm{x}_{\mathrm{i}}^{\mathrm{t}}\right)}{\mathrm{d}_{\mathrm{v}}^{\mathrm{t}}\left(\mathrm{y}_{\mathrm{i}}^{\mathrm{t}}, \mathrm{x}_{\mathrm{i}}^{\mathrm{t}}\right)}} \\
& \mathrm{SECH}=\frac{\mathrm{d}_{\mathrm{c}}^{\mathrm{t}+1}\left(\mathrm{y}_{\mathrm{i}}^{\mathrm{t}+1}, \mathrm{x}_{\mathrm{i}}^{\mathrm{t}+1}\right) * \mathrm{~d}_{\mathrm{v}}^{\mathrm{t}}\left(\mathrm{y}_{\mathrm{i}}^{\mathrm{t}}, \mathrm{x}_{\mathrm{i}}^{\mathrm{t}}\right)}{\mathrm{d}_{\mathrm{v}}^{\mathrm{t}+1}\left(\mathrm{y}_{\mathrm{i}}^{\mathrm{t}+1}, \mathrm{x}_{\mathrm{i}}^{\mathrm{t}+1}\right) * \mathrm{~d}_{\mathrm{c}}^{\mathrm{t}}\left(\mathrm{y}_{\mathrm{i}}^{\mathrm{t}}, \mathrm{x}_{\mathrm{i}}^{\mathrm{t}}\right)}
\end{aligned}
$$

where $\mathrm{c}$ and $\mathrm{v}$ represent constant returns to scale and variable returns to scale, respectively. 
PECH mainly captures changes in managerial performance (by either following best management practices or choosing perfect input combinations) of the firm.

Microeconomic theory proves that one of the fundamental objectives of a firm is to operate at its most productive size. If the size of the firm is too large or too small, it may not be efficient to reduce inputs such as cost or increase outputs such as revenue. In the current study, SECH reflects how optimum the scale size of the institution is in terms of using fixed inputs to increase the number of loans and borrowers.

Apart from internal factors, external factors such as social-economic-political situations can also play an important role on the efficiency of a firm. To take into account the impact of such factors on the technical efficiency scores (generated by the non-parametric analysis), a parametric analysis is conducted using the following latent variable model:

$$
\mathrm{y}_{\mathrm{i}}^{*}=\beta \mathrm{x}_{\mathrm{i}}+\varepsilon_{\mathrm{i}}
$$

where $\mathrm{x}_{\mathrm{i}}$ represents a vector of external variables, $\beta$ is a vector of unknown parameters to be estimated, and $\varepsilon_{\mathrm{i}}$ is a random error. The latent variable $y_{i}^{*}$ is tied to the observed technical efficiency scores by the following measurement model:

$$
y_{i}=\left\{\begin{array}{c}
y_{i}^{*} \text { if } 0<y_{i}^{*}<1 \\
1 \text { if } y_{i}^{*} \geq 1 \\
0 \text { if } y_{i}^{*} \leq 0
\end{array}\right.
$$

Since the technical efficiency scores range between zero and one, either Tobit or truncated regressions can solve the problem in equation 12 (Long \& Freese, 2006). Although parameters generated by a truncated regression are closer to true values than those produced by a Tobit regression (Simar \& Wilson, 2007), Tobit regression is widely applied. In addition, no observations are excluded from the data set used for the current study. For this reason, the present study applies Tobit regressions.

\subsection{Data Source, Descriptive Statistics and Variable Description}

\subsubsection{Data Source and Descriptive Statistics}

The data used in the current study are gathered from the MIX (https://www.themix.org/). In particular, 39 MFIs are selected among those operating in India during 2008 and 2012. These MFIs continuously operated during the study period and have sufficient input and output variables for the current study. The 39 MFIs form a balanced panel data set and their descriptive statistics are presented in Table 1. All the monetary values in this study are deflated using a GDP deflator calculated from data obtained from Penn World Table 9.0 at 2011 prices (Coelli et al., 2005).

Results from Table 1 show that the means of the variables that represent the size of profit MFIs, such as gross loan portfolio, number of active borrowers, number of loans outstanding, number of offices, total value of assets, liability, personnel and number of loan officers, are significantly higher those of non-profit MFIs. Also, the means of borrowers per staff member and borrowers per loan officer of non-profit MFIs are higher than those of profit MFIs. In addition, the mean of the cost per borrower of non-profit MFIs is lower than that of profit MFIs.

Table 1. Descriptive statistics

\begin{tabular}{lccccc}
\hline Variable & Obs $^{\mathrm{a}}$ & Mean & Std. Dev. $^{\mathrm{b}}$ & Min & Max \\
\hline \multicolumn{1}{c}{ Outputs } & & & & & \\
Gross loan portfolio (USD 1,000) & 195 & $318,293.90$ & $603,066.20$ & 862.32 & $3,559,623.00$ \\
Non-profit & 60 & $99,006.82$ & $237,613.10$ & 862.32 & $1,308,373.00$ \\
Profit & 135 & $415,754.90$ & $685,984.20$ & $4,242.32$ & $3,559,623.00$ \\
Number of active borrowers (persons) & 195 & $586,643.90$ & $1,069,540.00$ & $2,806.00$ & $6,242,266.00$ \\
Non-profit & 60 & $192,168.90$ & $399,583.50$ & $2,806.00$ & $2,314,075.00$ \\
Profit & 135 & $761,966.10$ & $1,218,676.00$ & $8,234.00$ & $6,242,266.00$ \\
Number of loans outstanding (loans) & 195 & $652,972.90$ & $1,164,342.00$ & $1,539.00$ & $6,242,266.00$ \\
Non-profit & 60 & $222,567.30$ & $524,578.00$ & $2,806.00$ & $3,105,254.00$ \\
Profit & 135 & $844,264.30$ & $1,312,153.00$ & $1,539.00$ & $6,242,266.00$ \\
\hline
\end{tabular}


Table 1 (continued). Descriptive statistics

\begin{tabular}{|c|c|c|c|c|c|}
\hline Variable & $\mathrm{Obs}^{\mathrm{a}}$ & Mean & Std. Dev. $^{\mathrm{b}}$ & Min & Max \\
\hline $\begin{array}{l}\text { Borrowers per staff } \\
\text { member (persons) }\end{array}$ & 195 & 339.10 & 304.62 & 31.00 & $2,100.00$ \\
\hline Non-profit & 60 & 419.12 & 478.63 & 31.00 & $2,100.00$ \\
\hline Profit & 135 & 303.54 & 171.27 & 47.00 & $1,388.00$ \\
\hline $\begin{array}{l}\text { Borrowers per loan } \\
\text { officer (persons) }\end{array}$ & 195 & 829.75 & $1,356.15$ & 55.00 & $10,775.00$ \\
\hline Non-profit & 60 & 970.20 & $1,803.40$ & 55.00 & $8,905.00$ \\
\hline Profit & 135 & 767.33 & $1,103.59$ & 98.00 & $10,775.00$ \\
\hline \multicolumn{6}{|l|}{ Inputs } \\
\hline Offices (offices) & 195 & 230.18 & 414.18 & 4.00 & $2,380.00$ \\
\hline Non-profit & 60 & 57.40 & 73.96 & 4.00 & 301.00 \\
\hline Profit & 135 & 306.97 & 476.06 & 5.00 & $2,380.00$ \\
\hline Assets (USD 1,000) & 195 & $344,296.10$ & $628,133.50$ & 963.91 & $3,352,696.00$ \\
\hline Non-profit & 60 & $114,895.60$ & $272,370.60$ & 963.91 & $1,523,881.00$ \\
\hline Profit & 135 & $446,251.90$ & $710,293.50$ & $7,999.49$ & $3,352,696.00$ \\
\hline Liability (USD 1,000) & 195 & $81,622.63$ & $146,583.70$ & 176.16 & $816,870.90$ \\
\hline Non-profit & 60 & $31,109.35$ & $78,399.16$ & 176.16 & $428,890.30$ \\
\hline Profit & 135 & $104,073.00$ & $163,557.80$ & 270.64 & $816,870.90$ \\
\hline Personnel (persons) & 195 & $1,890.98$ & $3,330.86$ & 15.00 & $22,733.00$ \\
\hline Non-profit & 60 & 695.00 & $1,203.90$ & 15.00 & $5,861.00$ \\
\hline Profit & 135 & $2,422.53$ & $3,807.77$ & 104.00 & $22,733.00$ \\
\hline Loan officers (persons) & 195 & $1,179.53$ & $2,169.59$ & 2.00 & $15,331.00$ \\
\hline Non-profit & 60 & 403.02 & 658.64 & 5.00 & $2,612.00$ \\
\hline Profit & 135 & $1,524.65$ & $2,496.76$ & 2.00 & $15,331.00$ \\
\hline $\begin{array}{l}\text { Cost per borrower } \\
\text { (USD 1,000) }\end{array}$ & 195 & 0.06 & 0.07 & 0.01 & 0.58 \\
\hline Non-profit & 60 & 0.06 & 0.07 & 0.01 & 0.38 \\
\hline Profit & 135 & 0.07 & 0.07 & 0.01 & 0.58 \\
\hline \multicolumn{6}{|l|}{ External } \\
\hline Population (persons) & - & $1,230,000,000.00$ & $26,100,000.00$ & $1,200,000,000.00$ & $1,260,000,000.00$ \\
\hline $\begin{array}{l}G D P(U S D \text { 1,000; } 2011 \\
\text { prices) }\end{array}$ & - & $5,500,000,000.00$ & $645,000,000.00$ & $4,660,000,000.00$ & $6,250,000,000.00$ \\
\hline $\begin{array}{l}\text { Number of MFIs } \\
\text { (institutions) }\end{array}$ & - & 110.00 & 17.00 & 87.00 & 125.00 \\
\hline
\end{tabular}

Source: Author's calculations.

${ }^{\mathrm{a}}$ Observations. ${ }^{\mathrm{b}}$ Standard Deviation.

\subsubsection{Variable Description}

The selection of inputs and outputs for DEA is slightly different between the production approach (Bassem, 2008; Haq, Skully, \& Pathan, 2010; Kipesha, 2013; Tahir \& Tahrim, 2013) and intermediation approach (Ahmad, 2011; Kipesha, 2013; Tahir \& Tahrim, 2013). The current study follows the production approach due to its popularity and the availability of the input and output variables. 
Five input variables, represent financial and human resources of the institutions, are selected for the present study. These variables include the number of offices (a proxy for the number of branches), assets, liability, cost per borrower, personnel and number of loan officers. Six selected output variables are gross loan portfolio, number of active borrowers, number of loans outstanding, borrowers per staff member and borrowers per loan officer.

Apart from the internal factors, it is necessary to take into account the impact of external factors (also known as environment factors) on the efficiency of the firm (or the MFI in the current study context). Based on literature and the availability of the data, three external variables are selected for the parametric analysis in the current study. These variables include population, GDP, and number of MFIs.

\section{Results and Discussions}

\subsection{The Efficiency of Microfinance Institutions}

4.1.1 The Efficiency of the Sampled Microfinance Institutions

Table 2. Malmquist Index summary of annual means

\begin{tabular}{lccccc}
\hline YEAR & EFFCH $^{\mathrm{a}}$ & $\mathrm{TECHCH}^{\mathrm{b}}$ & $\mathrm{PECH}^{\mathrm{c}}$ & $\mathrm{SECH}^{\mathrm{d}}$ & $\mathrm{TFPCH}^{\mathrm{e}}$ \\
\hline 2009 & 0.941 & 0.940 & 0.948 & 0.992 & 0.884 \\
2010 & 1.039 & 0.974 & 1.022 & 1.017 & 1.012 \\
2011 & 1.005 & 1.071 & 1.003 & 1.002 & 1.076 \\
2012 & 0.895 & 1.145 & 0.921 & 0.972 & 1.024 \\
Mean & $\mathbf{0 . 9 6 8}$ & $\mathbf{1 . 0 2 9}$ & $\mathbf{0 . 9 7 3}$ & $\mathbf{0 . 9 9 6}$ & $\mathbf{0 . 9 9 7}$ \\
\hline
\end{tabular}

Source: Author's calculations.

${ }^{a}$ Technical efficiency change. ${ }^{b}$ Technological change. ${ }^{c}$ Pure technical efficiency change. ${ }^{d}$ Scale efficiency change.

${ }^{\mathrm{e}}$ Total factor productivity change.

Although there are improvements in efficiency (represented by the total factor productivity change) in 2010, 2011 and 2012, its annual mean shows that the institutions are 99.7 per cent efficient, implying 0.3 per cent to be improved. This overall inefficiency is attributed by the inefficiency in 2009 (explained by time). The annual mean of the total factor productivity change can also be explained by its components. Despite an improvement of 2.9 per cent in technology, the technical inefficiency undermines the overall efficiency by 0.3 per cent. The technical efficiency change shows that the outputs could have been increased by 3.2 per cent without changing the inputs. Moreover, the decomposition of the technical efficiency change shows managerial underperformance ( 2.7 per cent to be improved) and the scale size of the institution is not completely productive ( 0.4 per cent to be adjusted).

Table 3. Malmquist Index summary of MFI means

\begin{tabular}{lrrrrr}
\hline MFI & EFFCH $^{\mathrm{a}}$ & TECHCH $^{\mathrm{b}}$ & PECH $^{\mathrm{c}}$ & SECH $^{\mathrm{d}}$ & TFPCH $^{\mathrm{e}}$ \\
\hline Adhikar & 1.066 & 1.011 & 1.072 & 0.994 & 1.078 \\
AML & 1.000 & 1.151 & 1.000 & 1.000 & 1.151 \\
Arohan & 0.978 & 1.057 & 0.979 & 1.000 & 1.034 \\
Asirvad & 0.884 & 1.000 & 0.884 & 1.000 & 0.884 \\
Asomi & 0.893 & 0.857 & 0.897 & 0.996 & 0.765 \\
Bandhan & 1.000 & 1.075 & 1.000 & 1.000 & 1.075 \\
BASIX & 0.964 & 1.100 & 0.960 & 1.004 & 1.061 \\
BJS & 1.031 & 0.949 & 1.000 & 1.031 & 0.978 \\
BSS & 0.958 & 1.065 & 0.963 & 0.994 & 1.020 \\
BWDA Finance & 0.881 & 1.003 & 0.882 & 0.999 & 0.883 \\
\hline
\end{tabular}


Table 3 (continued). Malmquist Index summary of MFI means

\begin{tabular}{|c|c|c|c|c|c|}
\hline MFI & $\mathrm{EFFCH}^{\mathrm{a}}$ & $\mathrm{TECHCH}^{\mathrm{b}}$ & $\mathrm{PECH}^{\mathrm{c}}$ & $\mathrm{SECH}^{\mathrm{d}}$ & $\mathrm{TFPCH}^{\mathrm{e}}$ \\
\hline Cashpor MC & 0.904 & 1.086 & 0.912 & 0.992 & 0.982 \\
\hline Equitas & 1.000 & 1.056 & 1.000 & 1.000 & 1.056 \\
\hline ESAF & 0.946 & 1.039 & 0.951 & 0.995 & 0.982 \\
\hline GFSPL & 0.960 & 1.029 & 0.983 & 0.977 & 0.988 \\
\hline $\begin{array}{l}\text { Grama Vidiyal } \\
\text { Microfinance Ltd. }\end{array}$ & 0.983 & 1.040 & 1.000 & 0.983 & 1.022 \\
\hline $\mathrm{HiH}$ & 0.821 & 1.039 & 0.819 & 1.002 & 0.852 \\
\hline $\begin{array}{l}\text { IDF Financial } \\
\text { Services }\end{array}$ & 1.054 & 0.893 & 1.054 & 1.000 & 0.941 \\
\hline IMPACT & 1.019 & 0.996 & 1.000 & 1.019 & 1.015 \\
\hline Mahasemam & 0.993 & 1.032 & 0.949 & 1.046 & 1.024 \\
\hline Mahashakti & 0.916 & 0.957 & 1.000 & 0.916 & 0.877 \\
\hline MMFL & 0.949 & 1.063 & 0.983 & 0.965 & 1.009 \\
\hline NEED & 0.966 & 1.027 & 1.032 & 0.936 & 0.992 \\
\hline RGVN & 0.959 & 1.071 & 0.958 & 1.001 & 1.027 \\
\hline Sanghamithra & 0.971 & 0.962 & 0.971 & 1.000 & 0.934 \\
\hline Sarala & 0.971 & 1.043 & 0.977 & 0.994 & 1.013 \\
\hline $\begin{array}{l}\text { Sarvodaya Nano } \\
\text { Finance }\end{array}$ & 1.002 & 1.191 & 1.000 & 1.002 & 1.194 \\
\hline SCNL & 0.967 & 1.033 & 0.961 & 1.006 & 0.999 \\
\hline SEWA Bank & 1.000 & 0.888 & 1.000 & 1.000 & 0.888 \\
\hline SHARE & 1.000 & 1.147 & 1.000 & 1.000 & 1.147 \\
\hline SKDRDP & 1.000 & 1.175 & 1.000 & 1.000 & 1.175 \\
\hline SKS & 1.020 & 1.096 & 1.000 & 1.020 & 1.119 \\
\hline SMILE & 0.903 & 1.052 & 0.919 & 0.982 & 0.950 \\
\hline Sonata & 0.900 & 1.020 & 0.900 & 0.999 & 0.917 \\
\hline Spandana & 1.000 & 1.103 & 1.000 & 1.000 & 1.103 \\
\hline Swadhaar & 0.990 & 0.883 & 0.992 & 0.998 & 0.874 \\
\hline $\begin{array}{l}\text { Trident } \\
\text { Microfinance }\end{array}$ & 1.011 & 1.141 & 1.009 & 1.003 & 1.153 \\
\hline Ujjivan & 0.973 & 0.979 & 0.983 & 0.990 & 0.952 \\
\hline VFS & 0.991 & 1.021 & 0.990 & 1.001 & 1.011 \\
\hline WSE & 1.000 & 0.924 & 1.000 & 1.000 & 0.924 \\
\hline Mean & 0.968 & 1.029 & 0.973 & 0.996 & 0.997 \\
\hline
\end{tabular}

Source: Author's calculations.

${ }^{a}$ Technical efficiency change. ${ }^{b}$ Technological change. ${ }^{c}$ Pure technical efficiency change. ${ }^{d}$ Scale efficiency change.

${ }^{\mathrm{e}}$ Total factor productivity change.

The total factor productivity change shows that 20 out of 39 the institutions are efficient. However, only nine out of the 20 institutions have all components efficient. In other words, only 9 out of 39 institutions are highly efficient. Of the 30 institutions that are not highly efficient, to be efficient, 24 ( 80 per cent) need to increase outputs without increasing inputs, 10 (33.3 per cent) need to apply or update new technology, 21 ( 70 per cent) 
need to improve managerial performance and 16 (53.3 per cent) need to adjust scale size.

4.1.2 The Efficiency of Profit versus Non-Profit and Regulated versus Non-Regulated Microfinance Institutions

Table 4. Malmquist Index summary of means for sub-samples

\begin{tabular}{lcccccc}
\hline Sample & EFFCH $^{\mathrm{a}}$ & $\mathrm{TECHCH}^{\mathrm{b}}$ & $\mathrm{PECH}^{\mathrm{c}}$ & $\mathrm{SECH}^{\mathrm{d}}$ & $\mathrm{TFPCH}^{\mathrm{e}}$ & $\mathrm{Obs}^{\mathrm{f}}$ \\
\hline Whole sample & 0.968 & 1.029 & 0.973 & 0.996 & 0.997 & 39 \\
Profit & 0.967 & 1.057 & 0.971 & 0.996 & 1.022 & 27 \\
Non-profit & 0.994 & 0.966 & 0.995 & 1.000 & 0.960 & 12 \\
Regulated & 0.960 & 1.044 & 0.965 & 0.995 & 1.002 & 28 \\
Non-regulated & 1.009 & 0.981 & 1.008 & 1.001 & 0.990 & 11 \\
\hline
\end{tabular}

Source: Author's calculations.

${ }^{\mathrm{a}}$ Technical efficiency change. ${ }^{\mathrm{b}}$ Technological change. ${ }^{\mathrm{c}}$ Pure technical efficiency change. ${ }^{\mathrm{d}} \mathrm{Scale}$ efficiency change.

${ }^{\mathrm{e}}$ Total factor productivity change. ${ }^{\mathrm{f}}$ Observations.

Compared to non-profit institutions, profit MFIs are more efficient in terms of productivity. The only contributing factor to the efficiency improvement of profit institutions is the improvement in technology (with an improvement of 5.7 per cent). The productivity growth in profit institutions could have been increased more by producing more outputs using fixed inputs, improving managerial performance and adjusting the scale size. Although the scale size of non-profit MFIs is productive, the total factor productivity shows inefficiency. To improve efficiency they need to produce more outputs without changing inputs. Also, applying or updating new technology and improving managerial performance will promote the efficiency in non-profit institutions.

Regulated institutions are more efficient than those that are not. It appears that technology plays an important role in improving efficiency of these institutions. In particular, the only component that improves the efficiency of regulated MFIs is technological change and the only factor that could have increased the efficiency of non-regulated institutions is technology.

\subsection{The Impact of External Factors on the Efficiency of the Microfinance Institutions}

Based on literature and the availability, three external variables are selected to examine their impact on the efficiency scores, which have been generated from the non-parametric analysis. The results are presented in Table 5 bellow.

Table 5. The impact of external factors on efficiency

\begin{tabular}{lcccccc}
\hline Efficiency Scores & Coef. $^{\mathrm{a}}$ & Std. Err. $^{\mathrm{b}}$ & $\mathrm{t}$ & $\mathrm{P}>\mathrm{t}$ & {$[95 \%$ Conf. } & Interval \\
\hline $\begin{array}{l}\text { Population (person) } \\
\text { GDP (USD 1,000; }\end{array}$ & -0.000000099 & 0.000000039 & -2.520000000 & 0.086000000 & -0.000000224 & 0.000000026 \\
$\begin{array}{l}\text { 2011 prices) } \\
\text { Number of MFIs }\end{array}$ & -0.000000004 & 0.000000002 & -2.290000000 & 0.083000000 & -0.000000008 & 0.000000001 \\
$\begin{array}{l}\text { (institution) } \\
\text { Constant }\end{array}$ & 0.066583800 & 0.061099900 & 1.090000000 & 0.356000000 & -0.127863200 & 0.261030900 \\
\hline
\end{tabular}

Source: Author's calculations.

${ }^{\mathrm{a} C}$ Coefficients. ${ }^{\mathrm{b}}$ Standard error.

The results in Table 5 show that the impact of population and GDP on the MFIs' efficiency (represented by Efficiency Scores, which are generated by the non-parametric analysis) are negative and significant at 10 per cent level. This could be explained that when the population is increasing MFIs tend to expand their coverage, and efficiency does not appear to be their priority. This finding is similar to one of the findings found by 
Takundwa and colleagues (2017). Expenditure of the government (a component of GDP) such as poverty reduction programs tends to compete with microfinance programs. Particularly, a number of poverty programs sponsored by the government usually have relatively lower interest rate or even free-interest rate, therefore, create a negative impact on the efficiency of the MFIs. The impact of the number of MFIs on the MFIs' efficiency is not statistically significant. Perhaps, the number of the MFIs in India at that time was not sufficient forcing the institutions to compete with each other to increase their efficiency.

\section{Conclusion}

The current study constructs a balanced panel data set on MFIs in India during 2008-2012 and employs a non-parametric analysis to examine the efficiency of the institutions. The results show a decrease of 0.3 per cent in productivity during the study period. The productivity growth is negative in 2009 , but positive in later years. The decomposition of the total factor productivity change shows that the technical efficiency change, pure efficiency change and scale efficiency attributes to the overall inefficiency of the institutions. The results also show that profit and regulated institutions are more efficient than non-profit and non-regulated institutions, respectively. The present study also performs a parametric analysis using a Tobit regression to analyse the impact of external factors on the efficiency of the institutions. The impact of population and GDP on the MFIs' efficiency is significant at 10 per cent level, but that of the number of MFIs is not statistically significant.

\section{References}

Agarwal, P. K., \& Sinha, S. (2010). Financial Performance of Microfinance Institutions of India. Delhi Business Review, 11(2), 37-46.

Ahmad, U. (2011). Efficiency Analysis of Micro-finance Institutions in Pakistan. Munich Personal RePEc Archive.

Annim, S. K. (2012). Microfinance Efficiency: Trade-Offs and Complementarities between the Objectives of Microfinance Institutions and Their Performance Perspectives. The European Journal of Development Research, 24(5), 788-807.

Bassem, B. S. (2008). Efficiency of Microfinance Institutions in the Mediterranean: An Application of DEA. Transition Studies Review, 15(2), 343-354.

Caves, D. W., Christensen, L. R., \& Diewert, W. E. (1982a). Multilateral Comparisons of Output, Input, and Productivity Using Superlative Index Numbers. The economic journal, 92(365), 73-86.

Caves, D. W., Christensen, L. R., \& Diewert, W. E. (1982b). The Economic Theory of Index Numbers and the Measurement of Input, Output, and Productivity. Econometrica: Journal of the Econometric Society, 1393-1414.

Coelli, T. J., Rao, D. S. P., O'Donnell, C. J., \& Battese, G. E. (2005). An Introduction to Efficiency and Productivity Analysis (2nd ed.). Springer Science \& Business Media.

Färe, R., Grosskopf, S., Norris, M., \& Zhang, Z. (1994). Productivity Growth, Technical Progress, and Efficiency Change in Industrialized Countries. The American Economic Review, 66-83.

Gebremichael, B. Z., \& Gessesse, H. T. (2016). Technical Efficiency of Microfinance Institutions (MFIs) Does Wwnership Matter? Evidence from African MFIs. International Journal of Development Issues, 15, 224-239.

Haq, M., Skully, M., \& Pathan, S. (2010). Efficiency of Microfinance Institutions: A Data Envelopment Analysis. Asia-Pacific Financial Markets, 17(1), 63-97.

Kipesha, E. F. (2012). Efficiency of Microfinance Institutions in East Africa: A Data Envelopment Analysis. European Journal of Business and Management, 4(17), 77-88.

Kipesha, E. F. (2013). Production and Intermediation Efficiency of Microfinance Institutions in Tanzania. Research Journal of Finance and Accounting, 4(1), 149-159.

Long, J. S., \& Freese, J. (2006). Regression Models for Categorical Dependent Variables Using Stata. Stata press.

Masood, T., \& Ahmad, M. (2010). Technical Efficiency of Microfinance Institutions in India-A Stochastic Frontier Approach. Munich Personal RePEc Archive.

Simar, L., \& Wilson, P. W. (2007). Estimation and Inference in Two-Stage, Semi-Parametric Models of Production Processes. Journal of Econometrics, 136(1), 31-64. 
Tahir, I. M., \& Tahrim, S. N. C. (2013). Efficiency Analysis of Microfinance Institutions in ASEAN: A Proposed Efficiency Framework. Interdisciplinary Journal of Research in Business, 3(4), 18-26.

Tahir, I. M., \& Tahrim, S. N. C. (2015). Efficiency and Productivity Analysis of Microfinance Institutions in Cambodia: A Dea Approach. International Review of Business Research Papers, 11(1).

Takundwa, R., Jowett, S., Mcleod, H., \& Peñaloza-ramos, M. C. (2017). The Effects of Environmental Factors on the Efficiency of Clinical Commissioning Groups in England: A Data Envelopment Analysis. Journal of Medical Systems, 41, 97.

\section{Copyrights}

Copyright for this article is retained by the author(s), with first publication rights granted to the journal.

This is an open-access article distributed under the terms and conditions of the Creative Commons Attribution license (http://creativecommons.org/licenses/by/4.0/). 